\title{
Women's Sex Representation in Comic Book
}

\author{
Aylin Gungor \\ Department of Graphic Design, Hacettepe University Fine Arts Institute, Turkey
}

\begin{abstract}
The representation of women has always been different in comics from past to present. Some women have been shown in the comics, in the role of being saved by a male superhero, or in a sexy female image with pornographic elements. The scarcity of female illustrators and writers, being male among publishers consists of the necessary information for the research of comics among the gender studies. Just as there are gender and objectification elements in real life, there are also these approaches to the female body in comics. Towards the 21 st century, together with the movements of feminism, both the technological conditions and the digitization of the comics have made women's representation a little more free. For this reason, the methodology of the research has been determined as Fourth Wave Feminism. Now, they can explain the female lesbian culture and sexual policies independently of society in the comics of Alison Bechdel's Fun Home and a series of images that depict Belden Sezen's A Snapshot. The handling of such female characters in comic books and graphic novels firstly enables the students to make accurate determinations while breaking the prejudice of the society, and then when determining the orientation of the young generation, and that women can live their identity freely as an individual. Based on all these information and results, in this research, the representation of women in comics will be explained through a historical evaluation and then criticized in terms of gender.
\end{abstract}

Keywords: comics, women, gender representation, objectification

\section{Introduction}

Nowadays, comic book theory is still unexplained. Therefore, many definitions have been made in the academic environment related to comic books from literature to art. These are expressions such as comic book is a technique where writing and visuality are combined or comic book is an art. In fact, comics are the closest form of expression to the human mind. Because the human mind is installed a system based on visual memory. The brain records each event as panels of visual memories. In the retrospect, the human perception of visuality has been blunted neuro-scientifically after the industrial revolution. Thus, we cannot see what we see, and we cannot grasp the combination of word and image. Therefore, "reading the image" seems to be important for the comics. In order to read the image, it is necessary to know exactly what the comic book is. Scott McCloud, in his book Understanding Comics, described the comic book as a medium or "sequential art" as a media form (McCloud, 2017, p. 9). Apart from what the comic is, it is an important fact for whom it is made. When the culture of the emergence of comic books is examined, cartoon-centered humorous aspect started for children and then this humorous aspect turned into a product that appeals to men, and it became an area where women took part in sexy elements. Later, due to political situations in countries such as war, comics have become a means of entertainment and hope for people. Especially in America, where the comic was born, people needing a savior due to wars led to the creation of some superheroes, mostly men. So are women in the comic industry as female characters or as a gender? As a gender representation, women have always been presented as a different indicator in the comic book market. These indicators are set for female characters, either sexy and pornographic, or in the role of a male superhero. Thus, masculine discourse is dominant in the comics and the picture of the woman by objectification enables women to move away from the comic book. For example, when looking at the history of the comic book, most women illustrators hidden their gender, either using the male name or using gender-free signatures to prevent gender discrimination. Naturally, in a male-dominated comic book industry, women felt the need to hide. Because the way or perception of male hegomania to see women is different. In general, as in human genetics, visual function comes before speaking. Surrealist painter Magritte, "in his painting The Key of Dreams, states that there is always a gap between words and objects seen" (Berger, 2008, p. 
7). This gap is enormous in terms of the representation of female gender in comics. But there is no obstacle in terms of not being overcome.

As a matter of fact, together with the technological developments in the new media, sociological and cultural studies have changed the areas and forms of women expressing themselves. Women can reach most people by opening a hashtag instead of doing street action like in the past. Expressed as the Fourth Wave of Feminism, this movement provides a free environment where women can express themselves as an identity. Kira Cochranehas been described fourth wave feminism as "the first wave of a new female raft that rises against sexism years later" (Cochrane, 2013, s. 16). With this movement, the possibilities of digital culture or social media channels have enabled comics to move away from the printed area and turn into technological elements. Now comics, which take their place on digital platforms as a moving item, can be watched just like an animation. That is why the representation of female characters in the comics has become freer, independent of real-life gender approaches. In fact, the aim of this study is to emphasize that the impact on the female representations reflected in all these comics also stems from the social and cultural structures of societies. Because today, they use social media, including young girls and women, children and adults, men as a means of propaganda or to make their voices heard and to show themselves. These channels, where women are more common, are able to make their voices alone in these environments without the need for a case, unlike women who gather movement and act as a group. However, in the past, most women have solved all their problems by explaining to each other due to the phenomenon of sisterhood in feminism. On the other hand, women in today's society can overcome their problems without anyone. Perhaps women can now provide the sisterhood principle with a visual and video shared on social media channels. Or a female character created exclusively for them in comics helps them express their feelings and problems as an identity and in terms of gender representation.

\section{Women and Comics}

Gender representation reflected by female characters in comics is very important for women that exist as an identity in societies. Because when the characters in the comic book industry are researched, it is seen that male characters are more than female characters. These female characters are always symbolized as strong men, beautiful women, or as individuals who are in a team (just like the Justice League), not as individuals. For example, characters such as Super Man and Spider Man were created, in the beginning with Super Girl, Cat Girl. Therefore, female characters are directed to be girls as gender. Later on, By giving up this girl's tendency to create characters, characters representing femininity come to the fore in graphic narratives such as Wonder Woman and Catwoman. As Kelly Sue DeConnick stated in the documentary She Makes Comics; "Representation is clearly vital" (Stotter, 2014, 0: 0: 57). However, it is not enough for girls to be mentioned in comics as women. At this point, Feminist approaches come to the fore. Feminism is a movement that defends the right of any female figure, be it black, queer, color women or lesbian. Therefore, comic books are not enough to represent these women, or female representation is marked by certain patterns. Perhaps the right perspective is that the representation of women created in the comics does not reflect the women of society. As a natural consequence of this situation, gender has been studied quite low in comics. The issue of women already contains many discussions in itself. If correct criticisms are made, the comic book industry is open to development.

In many societies, when the story of women's creation is researched, it is accepted that it is a Eve created from Adam. In other words, a woman is not an individual, she is a being made up of a man. Especially in religious stories, information is given that the woman is seductive and leads to sin. In most societies, women are always expressed as an entity that does not interfere with the job of the man. The situation is no different in Homer's Iliad and Odysseia epics. Homer's women are also systematically subject to men, whether they are rulers or slaves. According to this understanding, women can only be protected under men. Today, the same is true for the world of comics. There is also a male-dominated structure here. Comics in the industry are shown as a popular culture product that only intellectual men and boys love. Writing about how men and women are 
represented as a gender in the comics, Carolyn Cocca stated that "females are depicted from behind and on the side with large breasts, long hair, small waist and long legs, and are shown as muscular in males" (Cocca, 2014, p. 411) ( Figure 1). With these indicators, women are shown as a symbol of sexual power.

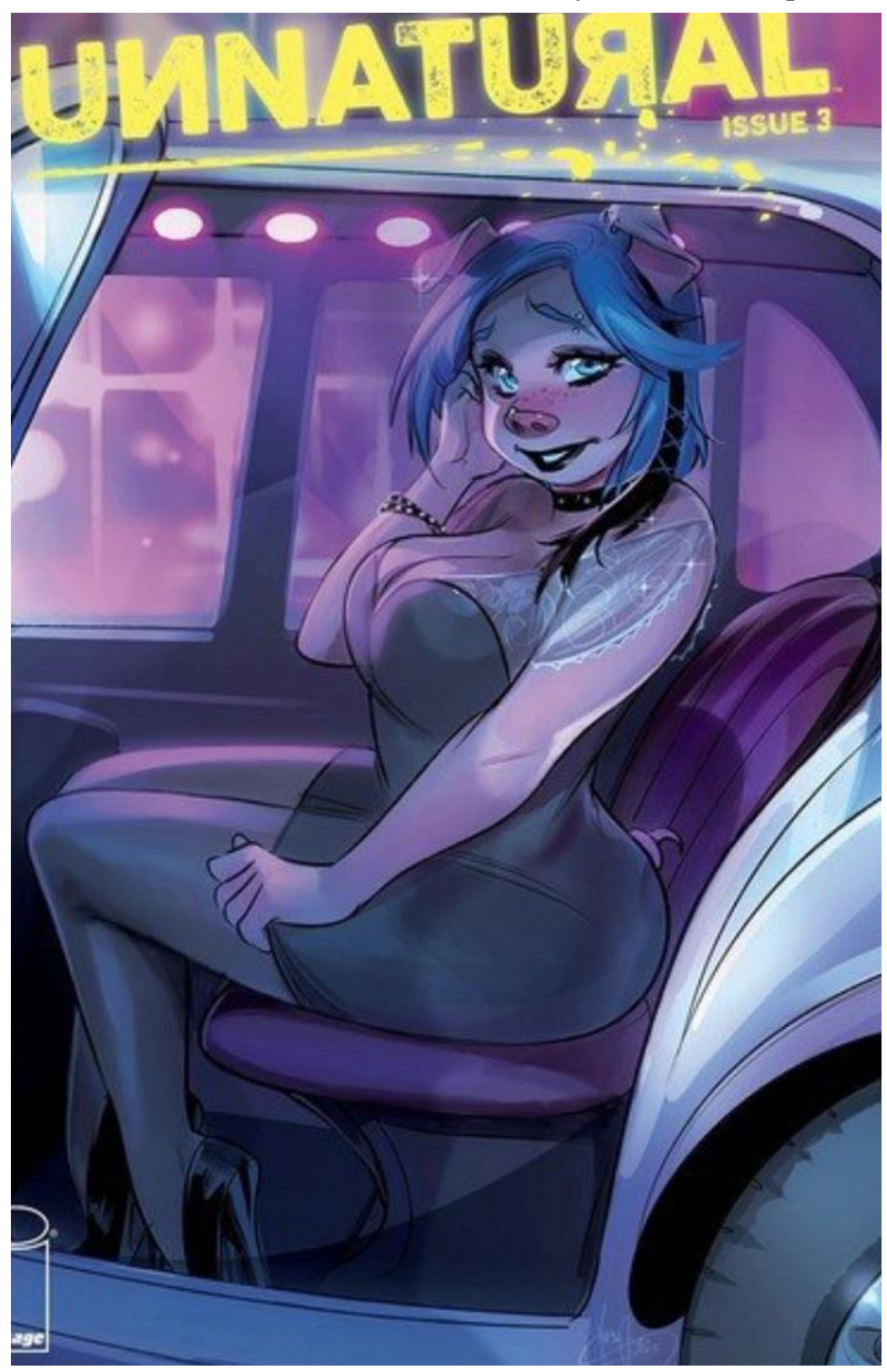

Figure 1 An example of a comic book cover with female characters looking sexy, Side view and Large breasted, Unnatural, Issue 3, Mirka Andolfo. https://www.adventuresinpoortaste.com/2018/09/04/unnatural-3review/.

Undoubtedly, showing women as a sexy and beautiful image in comics leads women to read less comic books. In this context, It would be a good idea to examine a feminist character created. Betty Boop, which was created as an animated character but later adapted to comics, became a "feminist icon" in the 1930s (Harness, 2010). Betty Boop is as smart and cute as she is sexy with her big eyes. With this feature, it differs from women created only as a sexy image in the comic. In addition, Betty Boop did not bow to men by encountering events such as harassment that women face in daily life. Therefore, Betty Boop has dealt with the representation of women in society from a point of view (Figure 2). According to Sheri Klein, who investigated the representation of women in the history of comics; she says that the depiction of female characters was created mostly for the "male gaze" since a predominantly male dominant structure prevailed in the comic book. That is why female characters, who 
turn into an object of desire in comic book panels, are objectified (Klein, 1991, p. 30). Although Betty Boop was objectified in the comic, she was able to revenge again from men in the comic

Undoubtedly, showing women as a sexy and beautiful image in comics leads women to read less comic books. In this context, It would be a good idea to examine a feminist character created. Betty Boop, which was created as an animated character but later adapted to comics, became a "feminist icon" in the 1930s (Harness, 2010). Betty Boop is as smart and cute as she is sexy with her big eyes. With this feature, it differs from women created only as a sexy image in the comic. In addition, Betty Boop did not bow to men by encountering events such as harassment that women face in daily life. Therefore, Betty Boop has dealt with the representation of women in society from a point of view (Figure 2). According to Sheri Klein, who investigated the representation of women in the history of comics; she says that the depiction of female characters was created mostly for the "male gaze" since a predominantly male dominant structure prevailed in the comic book. That is why female characters, who turn into an object of desire in comic book panels, are objectified (Klein, 1991, p. 30). Although Betty Boop was objectified in the comic, she was able to revenge again from men in the comic.
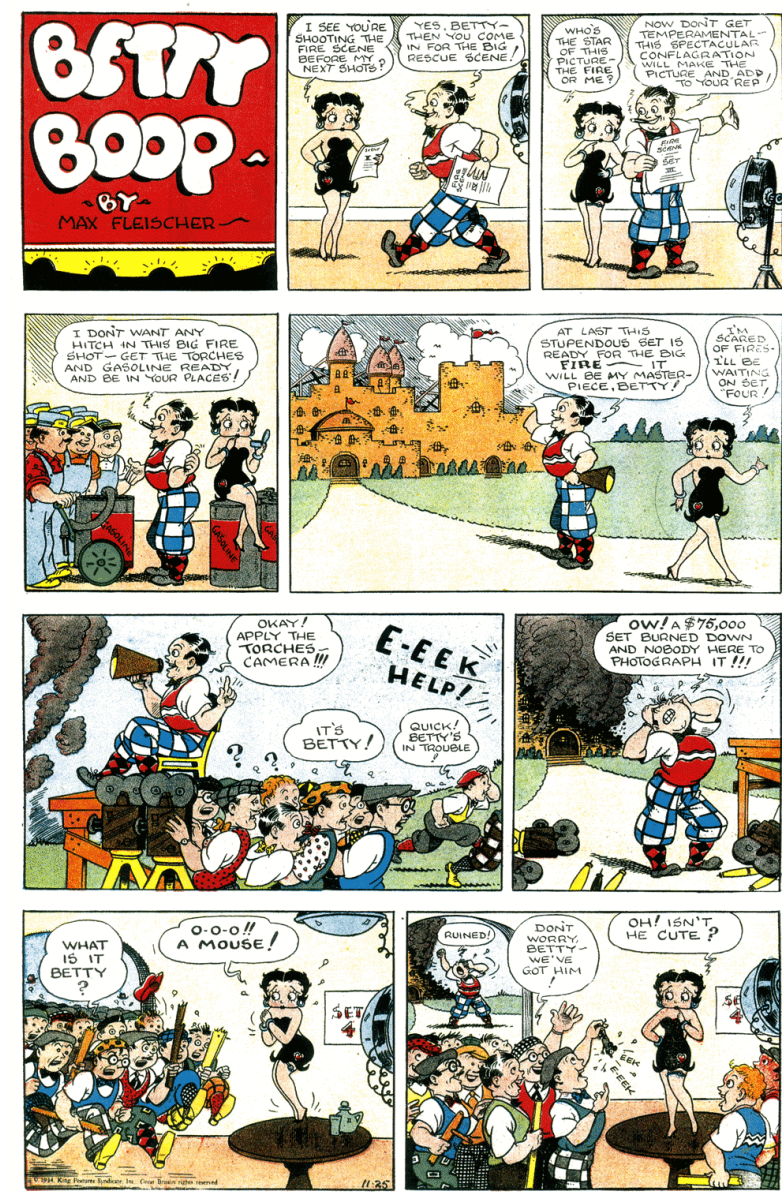

Figure 2 In addition to showing her sexuality, she is always portrayed as an innocent and sweet character. Betty Boop, Sunday 25 November 1934, by Max Fleischer. https://www.comicskingdom.com/trending/blog/2015/08/20/ask-the-archivist-betty-boop-strips.

Another character that draws attention in terms of female representation in the 1940s is Wonder Woman. Created by William Moulton Marston, Wonder Woman represented women who saved and contributed to the war after the First World War. She was able to use and fight all his powers just like a male superhero. Thus, Wonder Woman became the representative of women who are strong, feminine and able to do everything men 
do, unlike housewives and women in love working in a romantic world shown in visual media. In addition, Wonder Woman has become an advocate of feminism with views such as women understanding their potentials and demanding equality of rights (Sabin, 2003, p. 86). After the Second World War, the images of women in visual media reflected a conservative social and political climate. The place of women in the home was strengthened in the media with pastoral images of family life and happy housewives. Love and romance comics always empower women by making choices and sacrifices for love with a happy ending (Aktaran Klein, 1991, 31 ). But by the 1950s, the clothes that many super women characters were wearing and the extremely obscene visual elements created in their sex enabled the emergence of authority laws in the comics. Comics Code Authority banned display and explicit illustrations by the 1954s, which wanted to eliminate the excesses of the comic book industry and allow children to read characters that women are portrayed as healthy (Madrid, 2013, p. 31) (Figure 3).

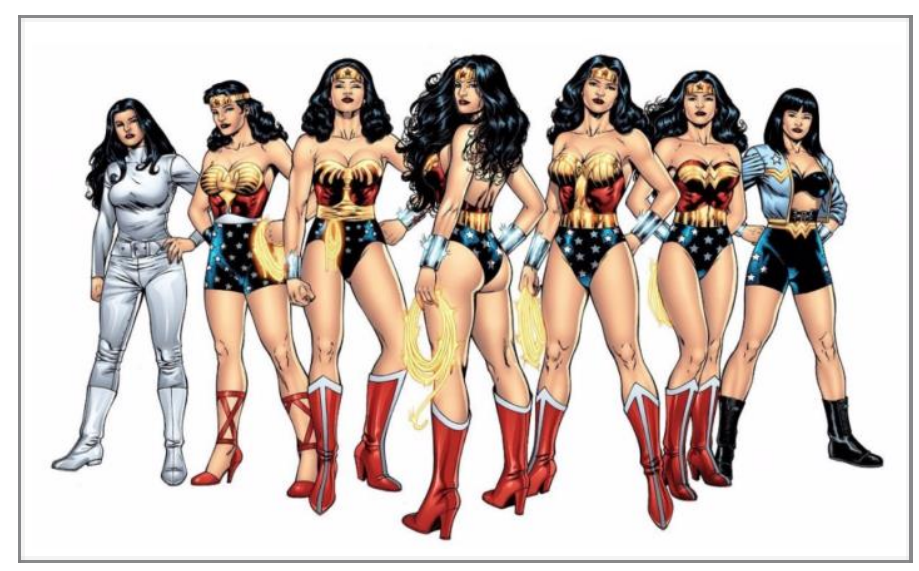

Figure 3 Wonder Woman dress from past and future. http://cbldf.org/2012/10/tales-from-the-code-whateverhappened-to-the-amazing-amazon-wonder-woman-bound-by-censorship/.

As a result, separate comic book types for girls and boys started to be launched in the comic book market. For example; romantic stories for girls and comics for adventure started to be released for boys. This led to gender discrimination and objectification in the comics created. In the 1970s, with the increase in women's movements and freedoms in America, several women who saw the male-dominant attitude in the comics draw the "It Ain't Me Babe", which is the first American comic book with its staff consisting entirely of women (Figure 4). 


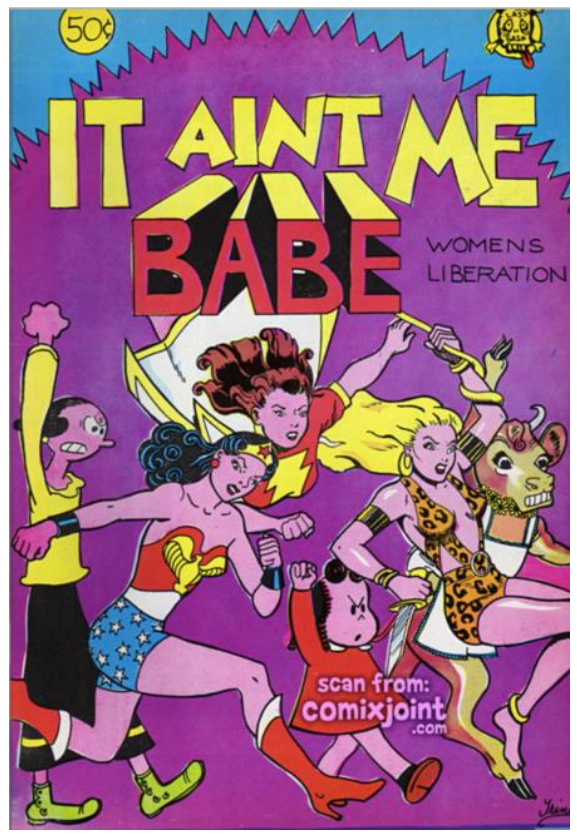

Figure 4 An exemplary comic magazine created by women, It Aint me Babe, 1970, July. https://comixjoint.com/itaintmebabe-1st.html

\subsection{Critics on Gender and Objectification}

The presence of masculine prejudice, which is predominant in the comic book industry, makes it imperative to examine the concept of gender over the characters created in the comics. Therefore, a view of feminist theory is required to address the concept of gender here. The explanation of the concept of sex used in feminist theory based on sociological and cultural norms, and the concept of sex used to express genetic sexual identity has led to the emergence of a new expression in non-English languages. Therefore, "gender" in languages that do not correspond to the term has been transferred to academic literature (Butler, 2018, p. 9). In fact, for women, gender is the definition of discrimination and misrepresentation of women as a gender in a socio-cultural environment. For this reason, comic books are the visual and aesthetic reflections of being represented as the media where gender and objectification are best reflected. Although this is not an accurate representation, it contains detailed graphic narratives that need to be studied in order to calculate the depth of field. As Hillary Chute puts it in her Graphic Women book: "The graphic narrative space brings the community of major elites to the table: hybridism, autobiography, theoretizing visual-related trauma, textuality that takes the body seriously. Graphical narratives are "feminists" because they display these interests (Chute, 2010, p.4). Because, just like in comic book narratives, a language that can fully or adequately represent women could not be developed in feminist theory. The most important reason for this is that the women in the comics act with the discourse of selling sex instead of being drawn like they are in real life, and the comic book audience is heterosexual men. Or "one of the main functions of female characters in male hero-centered comics is that they exist as "a heterosexual show" (Türk, 2013, p. 43).

Despite not having read comics, many women can see the objectification approaches to women only through visual media. According to Versaci, this situation; It originates from the "constructive construction of comic books" (Versaci, 2007). Thus, the objectification reflected in the female characters in the comics turned them into desired bodies. The pornography and sexy image indicator reduced the woman to the object. For example, a cute style was tried to be caught in the comics and cartoons made for children in the past. For this reason, gender characteristics of women or men were presented to the children by simplifying them (Robbins, 2002). As can be seen in Figure 5, the female cat was tried to be given a garlic identity by wearing a ribbon in the Garfield 
cartoon, applying a red lipstick to her lip and extending her lashes. This is another version of objectification. Today, along with the developments in feminism, the female characters in the comics have moved away from objectification and positive changes have begun to occur. Fourth wave feminism movement has a big share in these positive effects.
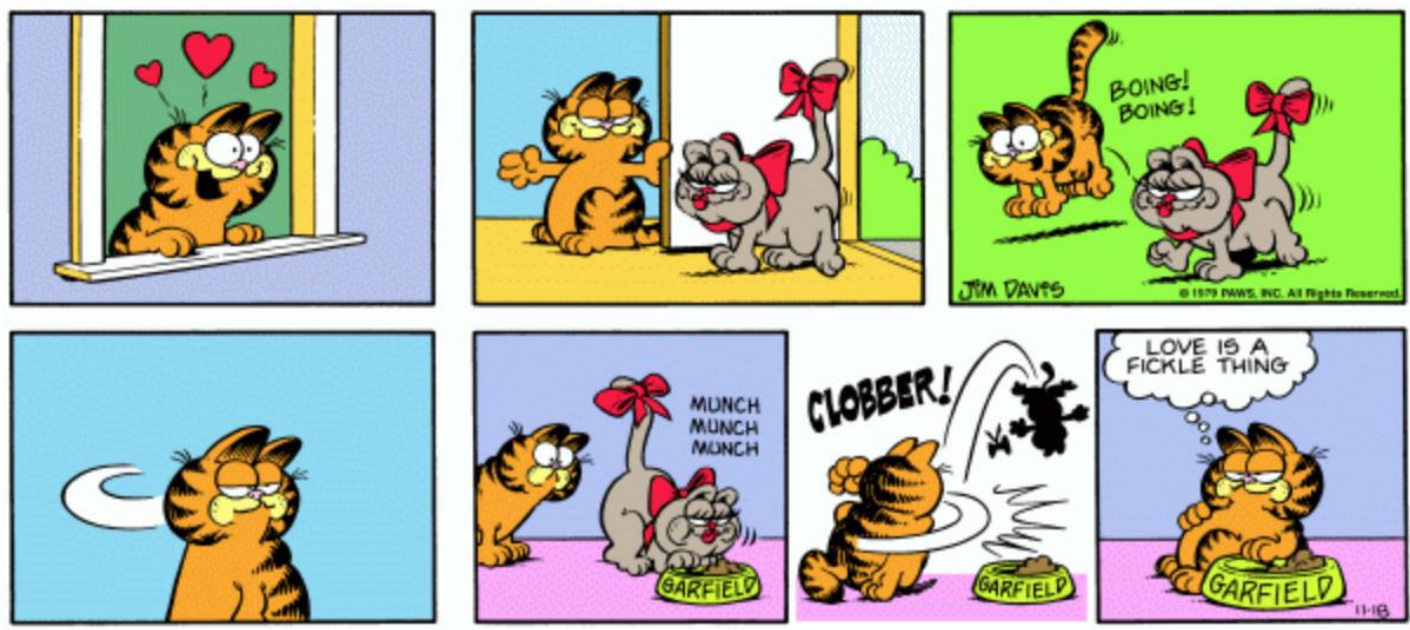

Figure 5 An example of Garfield and his lover objectification in the comic book, https://www.quora.com/Whatis-the-best-Garfield-comic.

\section{New Feminist Movements and Gender Approaches}

A new wave has emerged with the developments in the feminism movement and new media in the modern world. This movement, which develops mostly based on internet and social media, represents the limitlessness of women to express themselves as a gender. Because the history of Alisin Bechdol's discovery of his sexual identity coincides with the emergence of his father's interest in men. Fun Home explores the readability of the father figure in its center, while it allows the author to be close to touching his father by drawing his father, while the comic book style preserves the insoluble gaps of family history significantly (Chute, 2010, p. 175). In addition, the female characters created in Fun Home are reflected in a graphic novel as they exist in daily life without being exposed to approaches such as gender and objectification. Advocating that individuals should experience their sexual orientation freely, Fourth Wave Feminism provides an extraordinary example in female character creation by turning the cultural gender norms upside down with a lesbian character created in thegraphic novel (Figure 6). Revealing the representation of "feminist and queer women" under the roof of the Fourth Wave Feminism, Fun Home is a clear example of how comic books represent gender and sexuality. 


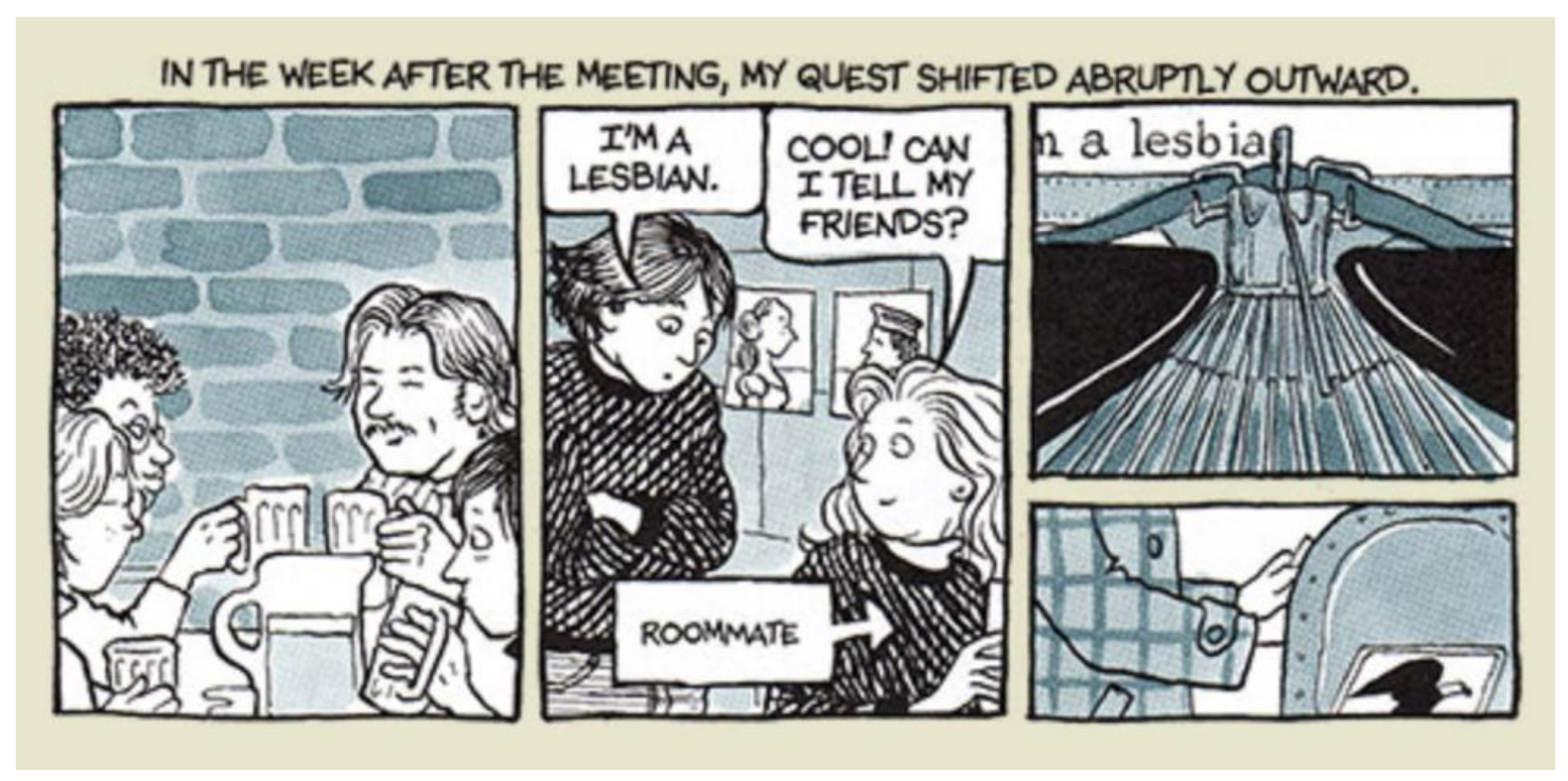

Figure 6 A panel from Alison Bechdel's graphic novel, Fun Home http://goodokbad.com/index.php/reviews/fun_home_review.

\begin{abstract}
"Sex activist Susie Bright argues that for an individual, the form of comics provides an invaluable space for nuanced desires: Apart from the comics, there is no other place where you can find the truthful and detailed pictures to show your life in stereotypical and delusional life using live photos" (Chute, 2010, p. 4).
\end{abstract}

Another comic book that questions the freedom of women's sexual orientation is the graphic novel called Snapshot of girl by Beldan Sezen. Beldan Sezen, who grew up in Germany as an immigrant girl, describes her emergence as a homosexual woman, Queer and LGBT problems in her graphic novel Snapshot of a girl. For example; In a panel of the Snapshot of a girl graphic novel, she asked her questions by asking herself, "What is the thing I like?" (See Image 7). In fact, Beldan felt that his lesbianism was loving himself. Thus, he clarified his forgotten sexual identity and femininity with this graphic novel. In addition, Beldan revealed the characters she created in the Snapshot of a girl graphic novel without objectification. Because the graphic novel was born in 2015, the fourth wave coincided with the period when feminism was felt the most. In this respect, the graphic novel literally addresses the issues that the fourth wave emphasizes due to the independent gender and sexual orientation it contains. 


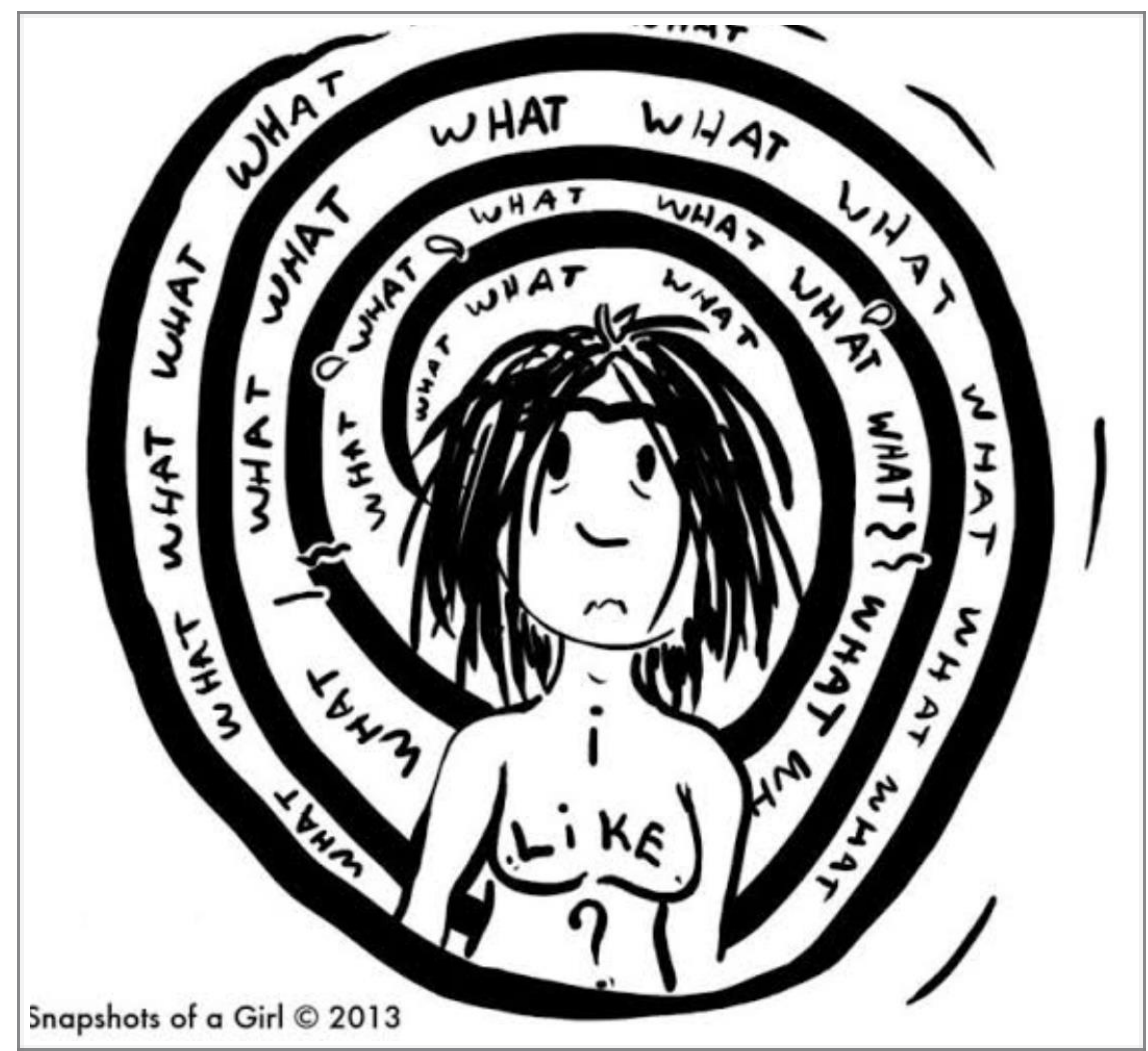

Figure 7 Beldan Sezen, Snapshots of a Girl, 2015, https://www.indiegogo.com/projects/snapshots-of-a-girl\#/.

Therefore, in the graphic novels and comics, women can express themselves without objectification, together with the fourth wave feminism movement. Instead of sexy and pornographic women that never exist, characters depicted based on women existing in society are more popular. But nowadays, something about comic books has changed. Instead of comic books that were previously published as printed publications, there are motion comic books today. With the impact of technological developments and new media environments, it has become digital in comics. In these animated comics, female characters can be described without any gender prejudices compared to the past. For example: The comic book called Lesbian Zombies from Outer Space is positive in terms of handling the life of lesbians in the context of gender, but it is a negative example because these women are objectified.

\section{Method}

Qualitative research method was used in this study and the content was created with the literature scanning technique. In the research, a historical subject classification was made initially, and the readings of both art and design were developed within this scope. In addition, the research does not only focus on the past, the information obtained is synthesized in terms of today and the scope of the subject requires a broad questioning.

\subsection{Sample / Working group / Participants}

Along with the technological and digital developments experienced today, the permeability of comic book and graphic novel disciplines increases and makes multidisciplinary studies mandatory. Therefore, the sample of the study is limited to objectification of female characters depicted in comics and graphic novels and evaluation of gender approaches. 


\subsection{Data Collection Tools}

In this research, based on the current research topic, national and international related periodicals, theses and articles, source books and internet were scanned, and the necessary data were obtained by following the current publications in the process.

\subsection{Process Steps}

In this research, firstly, resources about comics and graphic novels written with female characters were scanned and data on the subject were collected. Then, thesis and articles related to the subject were examined. The data obtained was compiled and a relational connection was established with the subject, and the scope and content of the subject were created. Also, the visuals supporting the subject were selected to provide diversity according to the discipline areas of art and design. Images are randomly selected from examples in each discipline area. Finally, the solution will be tried to be presented in the context of the information obtained by analyzing the subject.

\subsection{Data Analysis}

This research was carried out based on the Qualitative research method. Qualitative findings consist of three different types of data collection: (1) in-depth, open-ended interviews; (2) direct observation and (3) written documents (Patton, 2014, p.4). Therefore, in this study, firstly, literature review was made and literature review was completed. Later, current magazines and articles are examined, and the sample of the gender representation of women in the comics with the graphic novels called Fun Home and Snapshots of a girl is explained over the feminist movement. From the animated comics, the gender representation of women was investigated and Lesbian Zombies from Outer Space series was given as a negative example.

\section{Findings}

Whether in a comic book or a graphic novel, the processes of creating female characters will always be subject to reflection of cultural and social events. For this reason, the issues to be considered when creating female characters in the comics are as follows:

1. We must give up discourses expressing social gender approaches.

2. In the comic book, we must create women by avoiding sexual and pornographic elements.

3. We must stay away from all kinds of objectification attitudes.

\section{Conclusion}

Comic book discipline will either evolve by demolishing its patterns in the 21 st century or continue to create the same stereotypes for women. In this context, if the creation of the same types continues, the objectified female characters will lose their communication potential for the reader. For example; If a graphic novelist continues to treat women only through pornographic bodies as they do not update themselves according to the conditions of the age, this may cause the comic book industry to be subjected to pressure in a few years. At this point, a great responsibility falls to the illustrators, screenwriters, academicians, private sector employers and even art directors. In this connected global environment, academics will need to double their efforts while teaching future illustrators of both having a solid expertise and being flexible in terms of generalization. 
Perhaps the definition of the comic in the future will change so much that it can mean many different things besides the comic. For this reason, the processes of character creation need to be handled very well in institutions that are trained on comics. Neither the characters of the comics created in the past should be forgotten nor completely fantastic characters should be created. Female characters in the comics should be developed without ignoring the past, present and future. For this reason, the representation of women today should be reflected in the processes of creating women by including culture and feminist developments in character creation processes.

\section{Acknowledgments}

This work was supported by Hacettepe University Scientific Research Coordination Unit. Project ID: 9109

And in this research, my supervisor Prof. N. Şule ATILGAN, who provided me with all the support and information, I present my endless thanks to her.

\section{References}

Berger, J., 2008, Görme Biçimleri (İstanbul: Metis Yayıncıllk).

Butler, J., 2018, Cinsiyet Belası, Feminizm ve Kimliğin Altüst Edilmesi (İstanbul: Metis Yayıncılık).

Chute, H., 2010, Graphic Women: Life Narrative and Contemporary Comics (New York: Columbia University Press).

Cocca, C., 2014, The Broke Back Test: A Quantitive and Qualitative Analysis of Portrayals of Women in Mainstream Superhero Comics 1993-2013. Journal of Graphic Novels \& Comics, 5(4), 411-28.

Cochrane, K., 2013, All the Rebel Women, The Rise of The Fourth Wave of Feminism (UK: Guardian Book).

Harness, B., 2010, Happy Belated Birthday, Betty Boop!, Date of access: 01. 02. 2020. https://www.mentalfloss.com/article/25509/happy-belated-birthday-betty-boop adresinden tarihinde alınmıştır.

Klein, S., 1991, Breaking the mould with humour: Images of Women in the Visual Media, Art Education, 46(5), 29-37.

Madrid, M., 2013, The Supergirls, Fashion, Feminism, Fantasy, and History of Comic Book Heroines (USA:Exterminating Angel Press).

McCloud, S., 2017, Çizgi Romanı Anlamak (İstanbul: Sirtlan Kitap).

Patton, M, 2014, Nitel Araştırma ve Değerlendirme Yöntemi (Ankara: Pegem Akademi).

Robbins, T, 2002, Gender Differences in Comics. Image \& Narrative Issue 4. Gender Issue, Date of access: 01.02.2020. http://www.imageandnarrative.be/inarchive/gender/trinarobbins.htm.

Sabin, R., 2003, Comic Comix and Graphic Novels: A History of Comic Book (London: Phaidon Press).

Stotter, M., 2014, She Makes Comics (USA: Respect Film and Sequart) (Watched from DVD on 10.01.2020).

Türk, B. H., 2013., Hayali Kahramanlar Hakiki Erkekler, Çizgi Roman ve Fotoromanda Erkeklik Temsilleri Üzerine Denemeler (İstanbul: İletişim Yayınları).

Trier-Bieniek, A., 2015, Feminist Theory and Pop Culture (Rotterdam: Sense Publishers).

Versaci, R., 2007., This Book Contains Graphic Language: Comics as Literature (New York and London: Continuum).

Vincent, A. E., 2011., Performativity in Comics: Represent of Gender and Sexuality in Alison Bechdel's Fun Home (Colorado State Universtiy Department of English Master Thesis, Colorado). 